IRYNA KURLAK

\title{
WYBRANE ZAGADNIENIA PROBLEMATYKI PATOLOGICZNEGO HAZARDU W POLSCE
}

\begin{abstract}
Streszczenie: Wśród różnego rodzaju zjawisk patologicznych szczególne miejsce z uwagi na swoje dramatyczne konsekwencje zajmuje hazard. Samo uprawianie hazardu nie jest jeszcze patologią. Patologicznym staje się uzależnienie od tej czynności, kiedy to uprawianie hazardu staje się najważniejsze w życiu człowieka, zaczyna dominować w jego myśleniu, w uczuciach oraz w zachowaniu, w związku z czym powstają szkody, a w chwili zaprzestania grania pojawiają się przykre objawy odstawienia. Taki hazard został nazwany patologicznym i jest uznany za chorobę. W artykule omawia się prawdopodobne przyczyny uzależnienia od hazardu, mechanizmy i fazy nałogowego grania, charakteryzuje się osobowość patologicznego gracza, myślenie hazardzisty, konsekwencje grania, rodzinę hazardzisty i terapię patologicznego hazardu.
\end{abstract}

Słowa kluczowe: uzależnienie, patologia, hazard, choroba, konsekwencje, gracz, nałóg.

\section{Wprowadzenie}

Hazard nie jest zjawiskiem nowym, ponieważ dobrze znany był jeszcze w czasach starożytnych, kiedy zadłużony hazardzista mógł stać się niewolnikiem wierzyciela. Niemniej jednak dzisiaj hazard stanowi coraz to większy problem z kilku powodów. Jednym $z$ nich jest pojawienie się nowych rodzajów gier hazardowych, w tym związanych z rozwojem cywilizacji informatycznej. Ze względu na to hazard został nawet zakwalifikowany do tzw. nowych uzależnień - wszelkich istniejących obecnie uzależnień, w których substancje chemiczne nie odgrywają żadnej roli. Ich przedmiotem są działania akceptowane społecznie, wkomponowane w codzienne życie, mające jednak charakter obsesji i natręctw (Guerreschi 2004, s. 24). Innym powodem jest zwiększenie liczby osób, uprawiających hazard (w tym nałogowo), wśród których zdecydowaną większość stanowią ludzie młodzi.

Rynek gier hazardowych w Polsce zaczął się intensywnie rozwijać z początkiem lat 9o. XX wieku. Jak wynika z danych Ministerstwa Finansów w 2012 roku, w Polsce istniało 27 kasyn, ok. 300 salonów gier ulokowanych w największych 
miastach, a także ok. 1700 punktów bukmacherskich (Cabaj 2009, s. 8). W 2010 roku przez Krajowe Biuro ds. Przeciwdziałania Narkomanii zostało przeprowadzone ogólnopolskie badanie dotyczące udziału w grach hazardowych. Okazało się, że badani najczęściej deklarowali swój udział w grach losowych typu Lotto (38 proc.), loterie i inne gry za pomocą SMS-ów (18,7 proc.). W trzeciej kolejności uplasowały się zakłady bukmacherskie i automaty (Malczewski 2012, s. 14). W 2011 roku CBOS zrealizował badania na temat hazardu na ogólnopolskiej grupie reprezentatywnej osób w wieku powyżej 18 lat. Wyniki okazały się bardzo niepokojące. Według analiz najwyższy poziom ryzyka odnotowano w przypadku gier na automatach. Wśród osób grających w tego typu gry aż 40 proc. wykazuje symptomy uzależnienia (Malczewski 2011, s. 26), co aktualizuje tematykę badań naukowych nad tym rodzajem patologii społecznej.

\section{Definicje uzależnienia od hazardu}

Słowo „hazard” pochodzi z języka arabskiego i oznacza „kostkę”, jak i „grę w kości” (Hoffmann 2012, s. 25). Zgodnie ze Słownikiem wyrazów obcych PWN hazard to „ryzykowne przedsięwzięcie, którego wynik zależy wyłącznie od przypadku” (Tokarski 1980, s. 269).

Samo uprawianie hazardu nie jest jeszcze patologią. Patologicznym staje się uzależnienie od tej czynności. O uzależnieniu możemy mówić, gdy uprawianie hazardu staje się najważniejsze w życiu człowieka, zaczyna dominować w jego myśleniu, w uczuciach oraz w zachowaniu, powstają w związku z tym szkody, a w chwili zaprzestania grania pojawiają się objawy odstawienia (pogorszenia samopoczucia) (Wojewódzka 2012, s. 37). Określenie hazardu najczęściej słusznie kojarzy się z ryzykowną aktywnością, ślepym przypadkiem, rezygnacją z kontroli biegu wydarzeń, zawierzeniem skutków aktywności okolicznościom, na które nie mamy wpływu, z nadzieją, że ostateczny wynik okaże się dla nas pomyślny (Pospiszyl 2009, s. 197).

W terminologii dotyczącej omawianej tematyki wyróżnia się trzy rodzaje grania: 1) rekreacyjne (dla rozrywki, bez ponoszenia w związku z tym poważnych szkód w życiu); 2) problematyczne (zagrożone uzależnieniem); 3) patologiczne (nałogowe) (Lelonek-Kuleta 2010, s. 178). Właśnie definicję hazardu według American Psychological Association można uważać za określenie patologicznego rodzaju hazardu - zaburzenie, które polega na chronicznej i pogłębiającej się niezdolności opierania się impulsom nakłaniającym do gry oraz związanych z nią zachowaniom, które pogarszają, zakłócają lub uniemożliwiają funkcjonowanie w życiu osobistym, rodzinnym i zawodowym (Hoffmann 2012, s. 25).

Obok pojęcia „hazard” w literaturze funkcjonuje również inne pojęcie - „gamblerstwo" (z ang. gambling), które stosuje się zamiennie z hazardem. To pojęcie oznacza ryzykowanie czegoś wartościowego dla możliwej wygranej. Hazard patologiczny (gambling pathological) to zaburzenie osobowości, charakteryzujące się 
przewlekłą niemożnością powstrzymania się od gier hazardowych i powodujące destrukcyjne zachowania w życiu osobistym i społecznym. Siłą stymulującą zachowania patologiczne jest potrzeba przeżywania silnego napięcia, jakie pojawia się podczas gry (zwiększone wydzielenie adrenaliny). „Uzależnienie od hazardu jest chorobą postępującą, chroniczną, niewyleczalną, ale może być zatrzymana, podleczona" (Pierzchała, Cekiera 2008, s. 160).

\section{Diagnoza i objawy patologicznego hazardu}

Po raz pierwszy patologiczny hazard uznano jako zaburzenie zdrowia psychicznego w 1980 roku, w amerykańskiej klasyfikacji DSM III i umieszczono w grupie zaburzeń kontroli impulsów. W 1994 roku zostały opublikowane kryteria diagnostyczne patologicznego hazardu według DSM IV. Co najmniej pięć z przedstawionych poniżej uporczywych i nawracających zachowań związanych z hazardem wskazuje na uzależnienie:

- zaabsorbowanie hazardem, m.in. przeżywanie minionych doświadczeń związanych $\mathrm{z}$ graniem, planowanie kolejnych przedsięwzięć, myślenie o sposobach zdobycia pieniędzy na hazard;

- zwiększanie ilości czasu i pieniędzy przeznaczonych na udział w grze, aby osiągnąć ten sam pożądany poziom satysfakcji;

- podejmowanie powtarzających się bezowocnych wysiłków w celu ograniczenia lub zaprzestania uprawiania hazardu;

- odczuwanie niepokoju lub irytacji przy próbach ograniczania lub przerwania gry;

- traktowanie gry jako sposobu ucieczki od problemów lub środka na uśmierzenie poczucia bezradności, winy, lęku, depresji itd.;

- odgrywanie się, czyli próby odzyskania utraconych podczas gry pieniędzy;

- okłamywanie innych, m.in. członków rodziny czy terapeutów, w celu ukrycia rozmiarów swojej aktywności hazardowej;

- podejmowanie nielegalnych działań, takich jak m.in.: fałszerstwo, oszustwo, kradzież, malwersacja w celu zdobycia pieniędzy na grę;

- narażanie na szwank lub utratę z powodu zaangażowania w hazard ważnych związków interpersonalnych, pracy, możliwości edukacyjnych;

- szukanie u innych pomocy w zdobyciu pieniędzy na poprawę swojej złej sytuacji finansowej spowodowanej przez granie (Wojewódzka 2012, s. 38).

Kryteria diagnostyczne podaje także Światowa Organizacja Zdrowia. Obowiązująca od 1998 roku Międzynarodowa Klasyfikacja Chorób ICD-1o podnosi patologiczny hazard do rangi osobnego zaburzenia psychicznego F.63.0, które odnosi się do kategorii zaburzeń nawyków i popędów (impulsów), obok piromanii, kleptomanii, trichotillomanii (uporczywe wyrywanie włosów) oraz innych zaburzeń. Kiedy osoba poddaje się temu impulsowi, ma poczucie ulgi, które może być tak intensywne, że można je nazwać stanem euforycznym. Wielu 
hazardzistów przyznaje, że czują chęć życia tylko wtedy, gdy oddają się hazardowi (Lelonek-Kuleta 2011, s. 27).

Bardzo ważne znaczenie $\mathrm{w}$ diagnostyce patologicznego hazardu i poznaniu jego objawów mają różnego rodzaju kwestionariusze i testy. Można do nich zaliczyć test NORC Diagnostic Screen for Gambling Problems-Self Administered, opracowany w 1999 roku w oparciu o DSM-IV, kwestionariusz hazardu SOGS (South Oaks Gambling Screen), oparty o DSM-III oraz Kanadyjski Indeks Gier Hazardowych CPGI (Canadian Problem Gambling Indeks), opracowany przez Centre for Addiction and Mental Health w Toronto. W każdym z nich zaznacza się określoną liczbę pozytywnych odpowiedzi. Testy te pozwalają na zdiagnozowanie problemowego bądź patologicznego hazardu. Na bliższe przyjrzenie się swojemu graniu pozwala również znajdujący się na oficjalnej stronie Anonimowych Hazardzistów (http://www.anonimowihazardzisci.org) zestaw 20 pytań. Udzielenie co najmniej siedmiu twierdzących odpowiedzi na zamieszczone tam pytania może dać odpowiedź, czy osoba ulega patologicznemu hazardowi.

Uzależnienie od hazardu objawia się ciągłą bądź okresową utratą kontroli nad swoimi zachowaniami związanymi z graniem, usilnym zdobywaniem wszelkimi sposobami pieniędzy na grę, irracjonalnym myśleniem i kontynuowaniem swojego postępowania pomimo jego szkodliwych skutków. Zespół objawów zawiera trzy istotne wymiary zaburzeń osobowości: szkody psychofizyczne, utrata kontroli i zależność. Do utraty kontroli i do zależności od hazardu można zaliczyć: tolerancję, zespół objawów abstynencyjnych, zaabsorbowanie hazardem oraz traktowanie gier jako sposobu ucieczki od problemów życiowych. Specyficzny charakter patologicznego hazardu polega na tym, że osoba przez dłuższy czas może ukrywać swoje uzależnienie. Pojawienie się charakterystycznych sygnałów uzależnienia od hazardu, takich jak: długi, absencje w szkole, zakładzie pracy, wydawanie pieniędzy tylko na gry, nieuzasadnione pożyczki pieniędzy od rodziny i znajomych, izolowanie się od ludzi, przestępstwa, mogą być ewidentnymi kryteriami w diagnozowaniu stopnia uzależnienia od hazardu (Pierzchała, Cekiera 2009, s. 172).

\section{Prawdopodobne przyczyny uzależnienia od hazardu}

Wśród powodów choroby hazardowej wymieniany są zarówno czynniki biologiczne, psychologiczne, jak i środowiskowe. Rozpowszechniono hipotezę jakoby skłonność do hazardu była zależna od poziomu wydzielania się u człowieka endorfin. Badania jednak nie dały ostatecznej odpowiedzi potwierdzającej tę tezę. Nie udowodniono również dziedzicznego podłoża skłonności do hazardu. Zwrócono jednak uwagę na znaczenie przejmowanych od rodziców wzorców zachowań. Stwierdzono silną korelację między hazardem wśród młodych osób a ich rodziców. Ryzyko uzależnienia młodego człowieka wzrasta w przypadku nasilenia się sytuacji stresowych, rozwodu rodziców, śmierci lub poważnej choroby kogoś bliskiego, niedowartościowania oraz poczucia odrzucenia i braku kontroli nad 
życiem (Hoffmann 2012, s. 28). U kobiet hazard spełniał funkcję poprawienia sobie samopoczucia po poniesionych stratach, m.in. po śmierci bliskich, utracie pracy, zdrowia czy po doświadczeniu różnego rodzaju przemocy (Wojewódzka 2013, s. 42).

Ryzyko uzależnienia wzmacniają cechy osobowościowe gracza: jego niedojrzałość emocjonalna i społeczna, brak umiejętności radzenia sobie z emocjami, problemami, niskie poczucie własnej wartości, odczuwany brak akceptacji, szacunku, uznania ze strony otoczenia, dominująca potrzebę odniesienia sukcesu, wygrywania, bycia najlepszym, pociąg do ryzyka, poszukiwanie emocji, adrenaliny (Kalka 2013, s. 10).

Nierzadko wśród powodu „powrotu do kasyna” wymieniane jest doświadczenie wysokiej wygranej w pierwszej grze, „bycia w środowisku”, a także szczególnych emocji, gwarantujących wyjątkowe przeżycia. Hazard umożliwia wielu uzależnionym realizację fantazji o dużej wygranej, traktowany też bywa jako forma ucieczki - sposób na uniknięcie niepokojów lub problemów. Jak wykazują wyniki badań, młodzież w dużo większym stopniu (cztery razy więcej) niż osoby dorosłe podatna jest na uzależnienie od hazardu, zwłaszcza dotyczy to gier na automatach (Hoffmann 2012, s. 28).

\section{Mechanizmy i fazy uzależnienia od hazardu}

W przebiegu choroby hazardowej wyróżnić można różne fazy. Czas od rozpoczęcia grania od utraty kontroli nad swoim postępowaniem jest zróżnicowany. Najczęściej w literaturze przedmiotu opisywane są cztery fazy rozwoju uzależnienia od hazardu:

1) faza zwycięstw - polega na graniu okazjonalnym, fantazjowaniu na temat wielkich wygranych. W tej fazie duże wygrane powodują coraz to większe pobudzenie, coraz częstsze podejmowanie zakładów i coraz wyższe stawki w grze. Człowiek zaczyna wierzyć, że zawsze będzie wygrywać, a w przypadku osiągnięcia wielkiej wygranej dąży do jej powtórzenia, coraz częściej ryzykując utratę większej kwoty pieniędzy;

2) faza strat - grający stawiając na wysokie zakłady, naraża się na wysokie straty. Zaciąga wysokie pożyczki, które mają być przeznaczone na odegranie się, a w przypadkach powodzenia wygrane idą na spłatę długów. Hazardzista gra, stawiając na szali utratę pracy i nie licząc się z domowymi wydatkami, kłamie i zaczyna ukrywać swoje uzależnienie, cały czas wierzy, że wkrótce nastąpi wielka wygrana;

3) faza desperacji - najczęściej dochodzi do separacji od rodziny i przyjaciół oraz do utraty pracy. Narastające długi powodują panikę uzależnionego, zaś presja wierzycieli popycha go często ku popełnianiu przestępstw. Obciążenia te prowadzą z kolei do psychicznego wyczerpania gracza, w trakcie którego pojawiają się u niego wyrzuty sumienia, poczucie winy, bezradność i depresja;

4) faza utraty nadziei - najczęściej dochodzi w niej do rozpadu rodziny hazardzisty, a jego całkowite osamotnienie, poczucie braku pomocy i przede wszystkim 
ogromne długi wywołują w nim poczucie beznadziejności. W tej fazie najczęściej pojawiają się myśli, a niekiedy i próby samobójcze. Przed nałogowym hazardzistą pojawiają się cztery wyjścia: ucieczka w uzależnienie od alkoholu lub leków, więzienie, śmierć samobójcza lub z rąk wierzycieli albo szukanie pomocy (Hoffmann 2012, s. 27-28).

\section{Charakterystyka psychologiczna nałogowego gracza}

Wśród nałogowych hazardzistów dominują mężczyźni w wieku 20-45 lat, stanu wolnego. Poziom ich wykształcenia jest przeciętnie niższy niż większości populacji, z której się wywodzą. Zawody najczęściej przez nich wykonywane są związane z pracami fizycznymi, sezonowymi, bądź też osoby te prowadzą własną działalność gospodarczą przynoszącą niestałe, zróżnicowane dochody. Dużą grupę stanowią tu także osoby bezrobotne (Lelonek-Kuleta 2010, s. 179).

Analiza czynników psychologicznych współwystępujących z patologicznym hazardem pozwala wyodrębnić przede wszystkim zaburzenia osobowości i zachowania. Zauważa się, że nałogowi hazardziści istotnie częściej niż reszta populacji cierpią na zaburzenie kontroli impulsów, antyspołeczne zaburzenie osobowości, psychopatię, zaburzenie afektywne dwubiegunowe, a także bywają uzależnieni od środków psychoaktywnych. Poza tym graczy tych w większym stopniu niż resztę populacji cechują: potrzeba poszukiwania wrażeń, rozhamowanie behawioralne, podwyższony poziom impulsywności, trudności z przestrzeganiem norm społecznych, neurotyzm. U graczy patologicznych mają miejsce błędy poznawcze popełniane istotnie częściej niż u graczy rekreacyjnych, o czym będzie mowa dalej (Lelonek-Kuleta 2010, s. 179).

Osobę uzależnioną od hazardu charakteryzuje niezdolność i niechęć do zaakceptowania rzeczywistości, ucieczka do świata marzeń, niestałość emocjonalna, niedojrzałość i nieodpowiedzialność, ale także chęć wygodnego życia bez wysiłku (Pierzchała, Cekiera 2008, s. 163). Patologiczny hazardzista często ma potrzebę przeżywania stanów dość silnego pobudzenia, emocji - jest to dla niego przyjemne i część osób aktywnie poszukuje sytuacji mogących zagwarantować taki stan. Ich kontakt z rzeczywistością jest trudny, czują się w niej niepewnie i chętnie uciekają od niej na różne sposoby; mają łatwość posługiwania się nierealistycznym sposobem myślenia - uciekania w świat fantazji, złudzeń i iluzji (Derwich-Nowak 2013, s. 15).

Większość kobiet-hazardzistek przejawia objawy depresji, przewlekłego stresu pourazowego czy powikłanej żałoby, które nie były wcześniej rozpoznane ani leczone. Prawie każda próbowała w jakimś okresie życia „leczyć się” alkoholem, lekami uspakajającymi, większość nałogowo pali papierosy (Wojewódzka 2013, s. 42).

Wyróżnia się dwa rodzaje hazardzistów: 1) hazardzistów akcji, czyli osoby poszukujące w grze pobudzenia i 2) hazardzistów ucieczki, którzy grają, uciekając od swoich problemów. Hazardzistami akcji częściej stają się mężczyźni, a hazardzistami ucieczki - kobiety (Pindur i in. 2012, s. 82). 


\section{Myślenie hazardzisty}

Racjonalnie myślący gracz (grający w sposób umiarkowany, dla rozrywki) po kilku przegranych się nauczy, że nie jest możliwe przewidzenie wygranej i ograniczy swoją aktywność hazardową do poziomu dopuszczalnych według niego strat. Gracz patologiczny natomiast nie modyfikuje własnych przekonań pomimo kolejnych zdarzeń podważających ich wiarygodność (np. kolejna przegrana) (Lelonek-Kuleta 2013, s. 44).

Specyficzny sposób myślenia hazardzisty, wynikający m.in. z błędów poznawczych, jest podstawowym mechanizmem napędzającym chęć wygrania lub odegrania straconych już pieniędzy. Ten charakterystyczny sposób myślenia nazwano „nieracjonalnym” (iluzyjnym) myśleniem hazardzisty. Składają się na niego błędy poznawcze (paradoks hazardzisty, heurystyka dostępności, heurystyka reprezentatywności, heurystyka zakotwiczenia i dostosowania (pozorne korelacje, wiara w przesądy lub zabobony), przekonanie o swoim szczęściu i o swoim wpływie na wynik gry (tzw. iluzja kontroli), a także traktowanie przegranej jako „prawie wygranej" (Celebucka 2013, s. 43).

Jednym z podstawowych błędów poznawczych, obserwowanych u graczy, jest paradoks hazardzisty, zwany również złudzeniem gracza lub złudzeniem Monte Carlo. Polega on na traktowaniu niezależnych od siebie zdarzeń losowych jako zależnych od siebie. Nazwa złudzenie Monte Carlo pochodzi od zdarzenia, które miało miejsce w 1913 roku, i polegało na tym, że 26 razy z rzędu w ruletce w kasynie w Monte Carlo wypadł kolor czarny, a zdecydowana większość graczy stawiała na kolor czerwony, wierząc, że „w końcu musi się skończyć ta czarna seria”. W przypadku hazardzisty, który gra na automatach, paradoks ten przejawia się w myśleniu, że dana maszyna „musi teraz oddać”, ponieważ ktoś inny poprzednio na niej przegrał. Gracz wybiera maszynę, która w jego błędnym przekonaniu powinna teraz wypłacić wygraną (często najpierw obserwuje maszyny i zaczyna grać na tej, która w ostatnim czasie nie wypłacała nagrody). Hazardzista z czasem nabiera pewności, że jest w stanie przewidzieć wygraną i że jego obserwacje zaraz się sprawdzą. Wpada w iluzję kontroli (Celebucka 2013, s. 43).

Źródłem paradoksu hazardzisty może być heurystyka reprezentatywności, kiedy wydaje się mu, że bardziej prawdopodobne jest wylosowanie liczb skreślonych przypadkowo lub według jakiegoś klucza; tymczasem prawdopodobieństwo wylosowania każdej z liczb jest zawsze takie same (Niewiadomska i in. 2008, s. 53). Heurystyka dostępności polega na łatwiejszym wydobyciu z pamięci informacji o wygranych, a ignorowaniu informacji o przegranych (Celebucka 2013, s. 44). Heurystyka zakotwiczenia polega na oparciu swojego wnioskowania (zakotwiczeniu) na jakiejś informacji, a następnie dostosowaniu się do niej w celu wydania własnej oceny. Stosowanie tej heurystyki pozwala hazardziście wierzyć, że istnieje jakiś system w automatach, który należy poznać, aby móc wygrać (niektórzy hazardziści zgłaszali nawet chęć kupienia sobie automatu celem jego lepszego poznania), 
lub też, że ktoś znalazł strategię prowadzącą do wygrywania. Przejawem irracjonalnego myślenia u hazardzisty są przekonania o występowaniu pozornych korelacji (zabobonów). Gracz wierzy w przesądy, łącząc niezależne zdarzenia w jedną współzależność (Celebucka 2013, s. 44).

Przegrana w grze często może być postrzegana przez hazardzistę jako „prawie wygrana”, a więc jest tylko pewnym malutkim błędem, pomyłką, która zaraz może zostać naprawiona. „Prawie wygrana” działa tak samo jak realna wygrana, co potwierdziły badania (Celebucka 2013, s. 45).

Inną charakterystyczną cechą myślenia hazardzisty jest personifikacja i fantazjowanie. Personifikacja automatów do gier wyraża się w rozmawianiu z nimi, wyznawaniu im swoich uczuć, przeklinaniu ich w razie przegranej i innym podobnym postępowaniu. Fantazjowanie przybiera różne obrazy, poczynając od marzenia na temat wielkiej wygranej, a następnie fantazjowania już wyłącznie na temat choćby częściowego odegrania strat i spłacenia zaciągniętych długów (Celebucka 2013, s. 45).

\section{Konsekwencje grania}

Rozpoczynając grę, gracze nie zdają sobie sprawy z możliwych konsekwencji swojego postępowania, zwłaszcza że początkowe doznania są na ogół przyjemne i ekscytujące. Siła, z jaką gry hazardowe oddziałują na sferę emocji, prowadzi jednak do swoistego emocjonalnego wypalenia, znieczulenia, niemożności przeżywania emocji poza grą. Nałogowi hazardziści mówią wręcz o trwałym uszkodzeniu, upośledzeniu psychiki. W wielu przypadkach uczestnictwo w grze tworzy nową rzeczywistość, bardziej realną i ważniejszą dla gracza niż świat istniejący poza grą. Gracz wchodzi w rzeczywistość, w której nie kontroluje ilości czasu poświęcanego grze ani ilości wydawanych na nią pieniądzy. Brak kontroli upływającego czasu jest charakterystyczny głównie dla grających na automatach, w kasynach, salonach bingo (bo one są najłatwiej dostępne), nierzadkie są przypadki gry non stop przez kolejne dni (Kalka 2013, s. 11).

Jeden z najczęstszych skutków nałogowego grania jest problem niewypłacalności - stanowiący konsekwencję lekkomyślności, nieodpowiedzialności, ryzykanctwa, chciwości. Niewypłacalność i bankructwo postrzegane są jako ogromna porażka, krach, katastrofa o poważnych konsekwencjach dla wszystkich kluczowych sfer życia dłużnika, a także dla jego rodziny (Pomianowski 2012, s. 37). Dłużnik-hazardzista stopniowo popada w bezradność (Pomianowski 2013, s. 47). Aby zadośćuczynić takim problemom w Polsce, prowadzone są tzw. „Programy Wsparcia Zadłużonych".

Hazardzista zaniedbuje pracę lub naukę, swoje obowiązki wobec rodziny. Zaburzone zostają relacje międzyludzkie, w które gracz był wcześniej zaangażowany. Gracze często postrzegają bliskie sobie wcześniej osoby jako przeszkodę 
utrudniającą im poświęcenie się grze. Regułą jest okłamywanie otoczenia (rodziny, pracodawców) (Kalka 2013, s. 11).

Hazard często wiąże się z nadużywaniem substancji psychoaktywnych - alkoholu, papierosów, narkotyków, leków (Kalka 2013, s. 11). Utrata kontroli nad grą często prowadzi do wyniszczenia fizycznego. Występujący u tracących kontrolę graczy zanik potrzeb fizjologicznych, takich jak głód czy pragnienie, bezpośrednio odbija się na ich zdrowiu fizycznym. W skrajnych przypadkach mówi się też o zaniku kontroli nad oddawaniem moczu (Kalka 2013, s. 11).

Konsekwencją uzależnienia od hazardu są często stany depresyjne, prowadzące do myśli czy też prób samobójczych. Stany te w oczywisty sposób wiążą się z problemami finansowymi spowodowanymi grą. Uzależnienie od gier nieuchronnie prowadzi do takich problemów, jak: pożyczanie pieniędzy od rodziny, znajomych, wynoszenia z domu i sprzedawania różnych przedmiotów, niepłacenia rachunków, zaciągania kredytów, czasem kilku, kradzieży, utraty pracy. Nałogowe granie często kończy się bankructwem gracza, czego doświadczyli prawie wszyscy leczący się gracze oraz część jeszcze się nieleczących. Gracz staje się osobą wykluczoną społecznie: bez rodziny, ponieważ się rozpadła, bez pracy, przyjaciół, pieniędzy (Kalka 2013, s. 11).

\section{Rodzina hazardzisty}

Gdy jeden z członków rodziny nadmiernie angażuje się w granie, następują w rodzinie różne zmiany. Nie są one na początku dramatyczne - narastają wraz z uzależnieniem. Badacze problemu określają trzy fazy rozwoju rodziny z problemem hazardowym. Pierwsza faza to faza wypierania. Rodzina, gdy zauważa pierwsze niepokojące sygnały, racjonalizuje: ,to tylko raz”, „to nic poważnego”, „przegrał to go nauczy, już tego nie zrobi”, „obiecał, że nie będzie więcej grać”.

Druga faza to faza obciążenia. Zaprzeczanie problemom nie zatrzymuje nałogu, przeciwnie, nasila objawy. Hazardzista coraz więcej czasu poświęca na grę, a co za tym idzie - więcej pieniędzy przegrywa. Koncentracja na zdobywaniu nowych środków pochłania go całkowicie. Kontakty członków rodziny z innymi osobami ulegają rozluźnieniu, rodzina nie ma pieniędzy, aby zapewnić sobie i dziecku niezbędne potrzeby - pojawiają się złość, wstyd, poczucie winy czy krzywdy, uczucia te są jednak albo tłumione, albo impulsywnie rozładowywane.

Faza wyczerpania charakteryzuje rodzinę przeżywającą silny stres. U poszczególnych członków rodziny pojawiają się różne dolegliwości: bóle (głowy, mięśni, kręgosłupa), częste choroby, zaburzenia snu, kłopoty z apetytem. Przytłaczający stan zagrożenia, wstyd, który wzmacnia izolację, niemożność wykrzyczenia tego, co leży na sercu, powodują ogromne osamotnienie. Pilnie przestrzegane są zasady: „nie mów”, „nie czuj”, „nie ufaj” - utrudniające szukanie pomocy, zmuszające do zachowania w tajemnicy problemów życia rodzinnego. Rodzina jeszcze ufa w to, że jeżeli ureguluje finansowe zaległości, to skończy się problem z hazardem. Po czasie 
orientuje się, że całkowite wzięcie odpowiedzialności za postępowanie gracza czy kontrolowanie go jest nieskuteczne. Rodzinę ogarnia rozpacz.

Faza beznadziejności. Nasila się stan zagrożenia, lęku o przyszłość swoją i dzieci. Nie ma dnia, żeby nie myśleć o skutkach grania. Nie pozwalają o tym zapomnieć telefony z banków i od znajomych, od których hazardzista pożyczył pieniądze. Hazardzista może być tak zadłużony, że czasami trzeba nawet sprzedać mieszkanie czy wartościowe sprzęty, aby pokryć jego długi czy mieć na podstawowe potrzeby - jedzenie, przybory szkolne i inne rzeczy. Stan grozy jest nie do wytrzymania, wydaje się, że sytuacja jest bez wyjścia. U członków rodziny obserwuje się objawy depresyjne, myśli rezygnujące czy samobójcze. Czasami niektórzy sięgają po leki czy alkohol, a niekiedy idą zagrać, bo może im wreszcie uda się wygrać i spłacić długi (Wojewódzka 2012, s. 35-36). W niektórych przypadkach rodziny hazardzistów poszukują pomocy u prawników, aby zabezpieczyć się finansowo przed sytuacją bankructwa z powodu hazardu (Lipski 2012, s. 34).

Nierzadko zdarza się tak, że rodzina hazardzisty przychodzi do terapeuty od uzależnień w różnych momentach życiowych: w fazie obciążenia, wyczerpania bądź poczucia beznadziejności. Jedni przychodzą, gdyż niedawno dowiedzieli się o graniu najbliższej osoby i chcieliby wiedzieć, co robić w takiej sytuacji, inni - ponieważ podejmowane przez nich działania nie przyniosły skutku (Janke-Zarzycka 2013, s. 40).

\section{Terapia patologicznego hazardu}

Patologiczny hazard wymaga leczenia. Podstawowym warunkiem podjęcia terapii jest przyznanie się hazardzisty do nałogu i gotowość do rozpoczęcia leczenia. Pierwsza na świecie placówka lecząca osoby uzależnione od hazardu powstała w latach 70. XX wieku w Stanach Zjednoczonych. Pierwsze polskie placówki nastawione na pomoc terapeutyczną dla nałogowych hazardzistów rozpoczęły działalność w latach 9o. XX wieku. Jak wynika $\mathrm{z}$ danych NFZ, z powodu patologicznego hazardu w Polsce leczy się coraz więcej osób. O ile do 2006 roku liczba osób leczących się na koszt NFZ nie zmieniała się i wynosiła rocznie nie więcej niż 400 osób, to w 2007 roku takich osób było już 631, w 2008 roku - 948, zaś do września 2009 roku liczba ta wzrosła do 1340 . Pomocą hazardzistom zajmują się przede wszystkim poradnie leczące uzależnienie od alkoholu, gdyż brak jest państwowych placówek ukierunkowanych na leczenie od hazardu (Hoffmann 2012, s. 29).

Jak świadczą dane francuskie, większość pacjentów uzależnionych od hazardu cierpi na zaburzenia zdrowia psychicznego, stąd prawie 100 proc. $\mathrm{z}$ nich wymaga leczenia farmakologicznego (Lelonek-Kuleta 2013, s. 42). W zależności od potrzeby stosuje się stabilizatory nastroju, antydepresanty, leki przeciwpsychotyczne (Lelonek-Kuleta 2011, s. 30). Nałogowy gracz, który podejmuje terapię stacjonarną, często jest już po leczeniu psychiatrycznym czy pobycie w szpitalu, po próbie samobójczej. Taki pacjent ma nie tylko większe długi i trudności w ich spłacie 
z powodu braku pracy, ale nierzadko doświadcza zerwania więzi z bliskimi, separacji, rozwodu (Wojewódzka 2012, s. 35).

Ważne znaczenie w leczeniu hazardu ma terapia poznawczo-behawioralna. Może ona pomóc w „naprawieniu” błędnego spostrzegania sytuacji związanych $\mathrm{z}$ graniem. Leczenie obejmuje pięć etapów:

1) informowanie na temat gier, czyli wyjaśnienie znaczenia przypadku i ukazanie faktycznego braku wpływu gracza na wynik gry;

2) korygowanie błędnych przekonań polegających na rozpoznawaniu i likwidowaniu fałszywych poglądów na temat gry, takich jak wiara w sprzyjający los czy szczęśliwe rytuały;

3) poszukiwanie sposobów rozwiązywania problemów, co stanowi wspólne pacjenta i terapeuty - obmyślanie strategii poradzenia sobie z powstałymi w wyniku hazardu problemami;

4) trenowanie kompetencji społecznych, co wiąże się z budowaniem właściwych relacji z otoczeniem i szerszym środowiskiem społecznym, ćwiczeniem motywacji w procesie zdrowienia i wzmacnianiem poczucia własnej wartości;

5) zapobieganie nawrotom, które polega na zdobyciu umiejętności rozpoznawania symptomów grożących złamaniem abstynencji, jak i na nauczeniu się odpowiedniego reagowania, jeśli ich uniknięcie jest niemożliwe (Hoffmann 2012, s. 29).

Ważną rolę $\mathrm{w}$ procesie zdrowienia patologicznych graczy posiada ruch Anonimowych Hazardzistów (AH), działający na takiej samej zasadzie, jak ruch Anonimowych Alkoholików (AA). Członkowie AH dzielą się swoimi problemami i sposobami radzenia sobie z nimi oraz udzielają sobie wzajemnie wsparcia. Dla uzależnionej od hazardu młodzieży opracowany został program „Dziesięć Kluczowych Kroków" P. Bellringera (Stepulak 2011, s. 50).

Warto także podkreślić, iż w celu przeciwdziałaniu hazardowi w Polsce oraz podjęcia profilaktyki w tym zakresie powstał w 2009 roku Fundusz Rozwiązywania Problemów Hazardowych, na potrzeby którego w 2012 roku przeznaczono $18 \mathrm{mln}$ zł. Powstało pięć programów profilaktyki Ministra Zdrowia, wśród których znalazły się: program badawczy, program szkoleniowy, którego celem jest podnoszenie jakości zarówno programów profilaktycznych, jak i terapeutycznych, zwiększenie kompetencji zawodowych realizatorów tych programów, program dotyczący uzależnień behawioralnych, program działań informacyjno-edukacyjnych i ostatni, tzw. program leczniczy, który ma służyć rozwiązywaniu problemów wynikających z hazardu (Zdunek 2012, s. 19).

\section{Zakończenie}

Nałogowy hazard jest jednym z poważnych rodzajów patologii społecznej, która może doprowadzić w konsekwencji do zachowań desperackich i tragicznych w skutkach, nie tylko dla samej osoby uzależnionej, ale również dla jej najbliższej rodziny. Hazard jest chorobą, która wymaga specjalistycznego leczenia. Czynnikiem 
eliminowania konsekwencji hazardu jest właściwa terapia, a także różnego rodzaju programy wsparcia osób zadłużonych.

Ponieważ hazard dotyczy w większości ludzi młodych, potrzebna jest szeroka profilaktyka tego zjawiska, prowadzona przede wszystkim w szkołach, w tym przez osoby posiadające bezpośrednie doświadczenie w terapii hazardzistów. Niezbędną wiedzę na temat szkodliwości uzależnienia od gier hazardowych powinni posiadać również rodzice, a także studenci kierunków pedagogika, psychologia, praca socjalna, nauki o rodzinie. Alternatywą dla gier hazardowych winna stać się szeroka oferta różnego rodzaju zajęć rozwijających zainteresowania i zdolności młodzieży, odciągająca młodzież ze świata iluzji w świat realny, w którym istnieje wiele atrakcyjnych możliwości spędzania czasu wolnego, z korzyścią dla rozwoju osobistego i bez zagrożenia bankructwem i rozpaczą.

\section{Bibliografia}

Cabaj J. (2009). Gra w Internecie uwiodła Polaków. W: Hazard w sieci, Dąbrowski A. (red.). Warszawa: Difin, s. 6-12.

Celebucka J. (2013). Myślenie hazardzisty. „Świat Problemów”, nr 4, s. 43-46.

Derwich-Nowak A. (2013). Patologiczny hazard. Poradnik dla osób grajacych niebezpiecznie, zagrożonych schorzeniem, ich rodzin oraz terapeutów. Warszawa: Difin.

Guerreschi C. (2004). Nowe uzależnienia. Kraków: Wydawnictwo „Salwator”.

Hoffmann B. (2012). Uzależnienie od hazardu - specyfika, przyczyny, terapia. „Problemy Opiekuńczo-Wychowawcze”, nr 7, s. 23-30.

Janke-Zarzycka A. (2013). Przychodzi rodzina hazardzisty do terapeuty uzależnień. „Świat Problemów”, nr 2, s. 40-43.

Kalka J. (2013), Skazani na wykluczenie społeczne? „Świat Problemów”, nr 1, s. 5-12. Lelonek-Kuleta B. (2010). Uzależnienie od hazardu - zmienne psychospołeczne wspótwystępujące z nałogowym graniem. „Przegląd Psychologiczny”, nr 2, s. 176-191.

Lelonek-Kuleta B. (2011), Jak pracować z patologicznym hazardzista?, cz. I: Doświadczenia francuskie i polska praktyka. „Świat Problemów”, nr 8, s. 29-33.

Lelonek-Kuleta B. (2011). Pacjent nałogowo uprawiajacy hazard. „Świat Problemów”, nr 6, s. 27-31.

Lelonek-Kuleta B. (2013). Terapia patologicznego hazardu - doświadczenia kanadyjskie. „Świat Problemów”, nr 3, s. 42-46.

Lelonek-Kuleta B. (2013). Terapia patologicznego hazardu we Francji. „Świat Problemów", nr 10, s. 42-46.

Lipski E. (2012). Rozwiązania prawne zabezpieczające finansowo rodzinę z problemem hazardowym. "Świat Problemów”, nr 12, s. 34-38.

Malczewski A. (2011). Zjawisko uczestnictwa w grach losowych o charakterze hazardowym. „Świat Problemów”, nr 6, s. 23-26.

Malczewski A. (2012). Uczestnictwo w grach hazardowych w Polsce-analiza sytuacji. „Świat Problemów”, nr 4, s. 14-18. 
Niewiadomska I., Brzezińska M., Lelonek B. (2005). Hazard. Lublin: Wydawnictwo KUL.

Pierzhała K., Cekiera C. (2009). Człowiek a patologie społeczne. Toruń: Wydawnictwo Adam Marszałek.

Pindur A., Pomianowski R., Błaszczyński A. (2012). Hazard - historia, zagrożenia i drogi wyjścia. Poznań: Media Rodzina.

Pomianowski R. (2012). Problem zadłużenia $w$ terapii patologicznego hazardu. „Świat Problemów”, nr 10, s. 37-42.

Pomianowski R. (2013). Zadłużony hazardzista. „Świat Problemów”, nr 12, s. 44-48. Pospiszyl I. (2008). Patologie społeczne. Warszawa: PWN.

Słownik wyrazów obcych PWN (1980). Tokarski J. (red.). Warszawa: PWN.

Stepulak M. (2011). Dylematy moralne w pracy $z$ uzależnionymi od hazardu. „Remedium”, nr 7/8, s. 50-51.

Wojewódzka B. (2012). Diagnoza patologicznego hazardu. „Świat Problemów”, nr 5, s. 36-41.

Wojewódzka B. (2012). Problemy $w$ terapii patologicznego hazardzisty. "Świat Problemów", nr 7, s. 35-39.

Wojewódzka B. (2012). Rodzina hazardzisty. „Świat Problemów”, nr 8, s. 35-39.

Wojewódzka B. (2012). Uzależnienie od hazardu i substancji psychoaktywnych. „Świat Problemów”, nr 6, s. 33-36.

Wojewódzka B. (2013). Hazardzistki w terapii. „Świat problemów”, nr 9, s. 41-44. Zdunek A. (2012). Pierwsze doświadczenia z działania Funduszu Rozwiązywania Problemów Hazardowych. „Świat Problemów”, nr 4, s. 19-21.

\title{
SOME ISSUES OF PATHOLOGICAL GAMBLING IN POLAND
}

\begin{abstract}
Among the various types of pathological phenomena gambling holds a special place because of its dramatic consequences. Gambling is not a pathology in itself. It becomes a pathological dependence when it turns into the most important thing in life, begins to dominate the person's thoughts, feelings and behaviour and therefore damage is caused. Ceasing to play results in unpleasant withdrawal symptoms. Such gambling was denominated as pathological and is recognized as a disease. The article discusses the possible causes of gambling addiction, the compulsive mechanisms and phases of gambling, characterizes the pathological personality of the player, their way of thinking, the consequences of playing, the family of a gambler and the treatment of pathological gambling.
\end{abstract}

Keywords: addiction, pathology, gambling, disease, consequences, player.

Iryna Kurlak - profesor, doktor habilitowany. Zainteresowania naukowe: patologie społeczne, pedagogika resocjalizacyjna, wiktymologia, konfliktologia. Współredaktorka publikacji: Suicydologiczne aspekty patologii społecznej (Ostrowiec Świętokrzyski 2014), Wybrane zagadnienia problematyki pomocy i wsparcia $w$ rozwiązywaniu problemów ludzi 
w różnym wieku (Ostrowiec Świętokrzyski 2012), Człowiek w obliczu trudnej sytuacji życiowej (Sandomierz 2011), Wokół problematyki pomocy dziecku i rodzinie w sytuacji kryzysowej. Podejście interdyscyplinarne (Warszawa 2011), Współczesne zagrożenia psychospołecznego funkcjonowania człowieka (Ostrowiec Świętokrzyski 2010), Uwarunkowania, profilaktyka i resocjalizacja aspołecznych zachowań dzieci i młodzieży (Warszawa 2010), Pomoc dziecku i rodzinie w sytuacji kryzysowej: teoria, historia, praktyka (Sandomierz 2008). Adres do korespondencji: Wydział Nauk Pedagogicznych UKSW, ul. Wóycickiego 1/3, budynek 15, o1-938 Warszawa. Adres e-mailowy: i.kurlak@uksw.edu.pl. 